\title{
Division Solid Waste Generation and Composition in Kampala Capital City Authority, Uganda: Trends and Management.
}

\author{
${ }^{1}$ Nabukeera Madinah, ${ }^{2}$ Ali Boerhannoeddin, ${ }^{3}$ Raja Noriza Binti Raja Ariffin \\ ${ }^{1}$ Management Faculty Islamic University in Uganda P.O.box 2555 Kampala Uganda \\ ${ }^{2}$ Department of Administrative studies and Politics Faculty of Economics and Administration Kuala Lumpur \\ P.O. box 50603 Malaysia \\ ${ }^{3}$ Department of Administrative studies and Politics Faculty of Economics and Administration Kuala Lumpur
}

\begin{abstract}
Recognition of waste generation trends and composition is a significant phase towards planning, policy making, budget allocation, management and improving the state of solid waste for any particular country. The objective of this paper therefore was to discover the generation of waste by the five divisions of Kampala Capital City Authority (KCCA) and private sector as a quick fix to guide policy makers to make informed decisions in proper management of waste in Kampala.

In this paper, a qualitative method was used mainly observation and a few available documents. The researcher and research assistants recorded every refuse truck that off loaded at Kitezi Sanitary Landfill 24 hours a day for a period of one financial year (from July 2012-June 2013). The aim was to determine the number of tonnes per vehicle since the weigh bridge was nonfunctional. The waste tonnage was determined on the basis of the weigh bridge's archived information and with this information, the total waste produced by each division (daily, weekly and monthly) was quantified.

Results indicate that KCCA, a government representative body entrusted to manage Kampala, collects the biggest percentage of waste $(64.36 \%)$ generated compared to private sector $(35.64 \%)$, Furthermore, Central Division generates the highest tonnage of waste (64.171 tonnes) per year compared to other Divisions.

In conclusion we propose that government allocates funds according to percentage generation of waste and on this basis, KCCA needs to place emphasis on reducing waste generation by encouraging sustainable reuse and recycling as well as addressing key success factors that include expertise, awareness of the public, strengthening partnerships to pool resources and promoting advanced technology.
\end{abstract}

Key words: Solid waste generation, trends, characterization, management and KCCA performance

\section{Introduction}

As growth and productivity evolution increases in Uganda, the effect of solid waste is becoming more noticeable in society. As at May 2013, divisions of Kampala Capital City Authority (KCCA) generate about 29,537 tonnes per month compared to 350.975 tonnes of municipal solid waste (MSW) generated per year for the entire city. These estimations are conventional; the actual standards are perhaps higher than twofold this quantity. Garbage collection has increased from 54\% to 65.2\% in the last two years (Authority, 20012-2013). At present, Uganda spends about $\$ 10,654,811$ per year to collect $65.2 \%$ of generated garbage in Kampala.

The increasing urbanization of Kampala at a rate of $5.8 \%$ per year (UBOS, 2005) has resulted into deterioration of solid waste management services whose poor quality has caused a public outcry. There is therefore need for government to restore the situation (ERL, 2009) and ensure the composition, quality and quantification is kept up to date (Golooba-Mutebi, 2003; Manaf, Samah, \& Zukki, 2009; Matagi, 2002; OkotOkumu \& Nyenje, 2011; Samah et al., 2013; Tukahirwa, Mol, \& Oosterveer, 2010).

The characterization of waste varies from country to country and is directly associated with the pattern of its development and management given the variations in economic status (Achankeng, 2003). The growth of Urbanization in many countries did not spare Uganda and associated with it is the indiscriminate disposal of waste due to unawareness, which has caused man-made floods in the water channels draining low lying areas during rainy seasons (Achankeng, 2003; Matagi, 2002). Given this state of affairs, KCCA is expected to deal with environmental and management issues of solid waste as a result of increased population in the city that generates a proportional amount of waste. (Okot-Okumu \& Nyenje, 2011).

The divisions in Kampala have lamented that the amount of waste generated on daily basis over whelms their collection capacity due to limitations in budget allocations (Lambright, 2014; Liyala, 2011; OkotOkumu \& Oosterveer, 2010). Thus there is need for innovative approaches to deal with the challenges and this in turn requires accurate data as a quick fix to support government in decision making .Since Uganda is among the countries still promoting traditional methods of solid waste management, the solid waste flow, weights and percentage elements is useful data for planners in decision making. 
This paper therefore, aimed to: approximate the regular generation rate of different divisions under KCCA and private garbage collectors of municipal solid waste (MSW); identify the trends of garbage in KCCA to support knowledgeable resolutions; explore changes in MSW generation during the recentralisation of Kampala administration and; assess its performance as well as advise policy makers on the bigger picture of solid waste in order make informed decisions.

\section{Municipal solid waste Collection and composition}

According to the Solid Waste Management (SWM) Ordinance (KCC, 2000), the collection, transportation and disposal of garbage are the responsibility of KCCA and its five divisions. As at 2009, only 400-500 tonnes of garbage were collected per day. Currently, approximately 1,000 tonnes are being collected per day and disposed at the Kitezi Sanitary landfill. Despite the twofold improvement in the amount of waste collected, the efficiency is still low standing at only $65.2 \%$ in relation to the waste generated in the city. This implies that $34.8 \%$ of the garbage generated daily is not properly collected and disposed which has resulted into indiscriminate disposal by the public.

According to the (KCCA, 2013), 70-80\% of the garbage generated in the city is organic while the rest is inorganic comprising of glass, paper, metals construction and demolition waste as indicated in the waste stream on the following pie chart;

\subsection{Composition of solid waste in Kampala}

Figure 1: Composition of solid waste in Kampala

The composition of the generated waste was found to be 73.80 vegetable matter, $8 \%$ tree cutting, $5.50 \%$ street debris, $5.50 \%$ paper, $3.10 \%$ metal, $1.70 \%$ saw dust, $1.60 \%$ plastic and 0.90 glass. Glass represented the lowest composition while vegetable matter represented the highest.

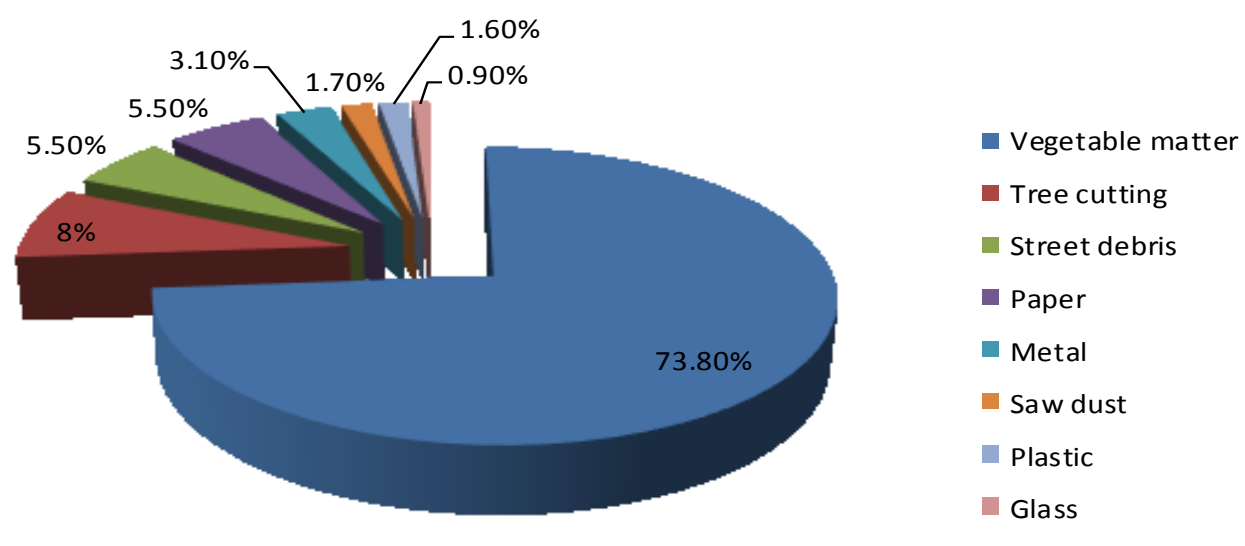

Source: KCCA 2013

\section{Methodology}

The study was carried out in KCCA within the five divisions (i.e., Kawempe, Kampala central, Lubaga, Makindye and Nakawa divisions) and the area studied is on scale of 1:32,700. Though Kampala is surrounded by an industrial area, our study covered only municipal waste. To carry out the study, weights of incoming waste in the refuse trucks was recorded before it was off loaded for sorting by the scavengers. The researcher and her team (ten research assistants) manually recorded information for 24 hours a day, seven days a week every month for a period of one year starting from July 2012- June 2013 financial year. We had 10 research assistants, 5 of which collected data during the day while the other five worked at night. Each research assistant was assigned one Division for recording tonnes of refuse delivered by the trucks. Every recorded truck would then off load the garbage in the tipping area allocated by landfill manager for a particular day with the help of truck guides. The tonnages were estimates based on the type of the refuse truck carrying garbage to the landfill guided by the archives of the weigh bridge records since it was nonfunctional for the period the data was collected. The raw data was totaled up to get the total weight of waste generated by each division. Methods employed was mainly observation and a few documents that were available.

\subsection{Map showing Kampala City Boundaries}




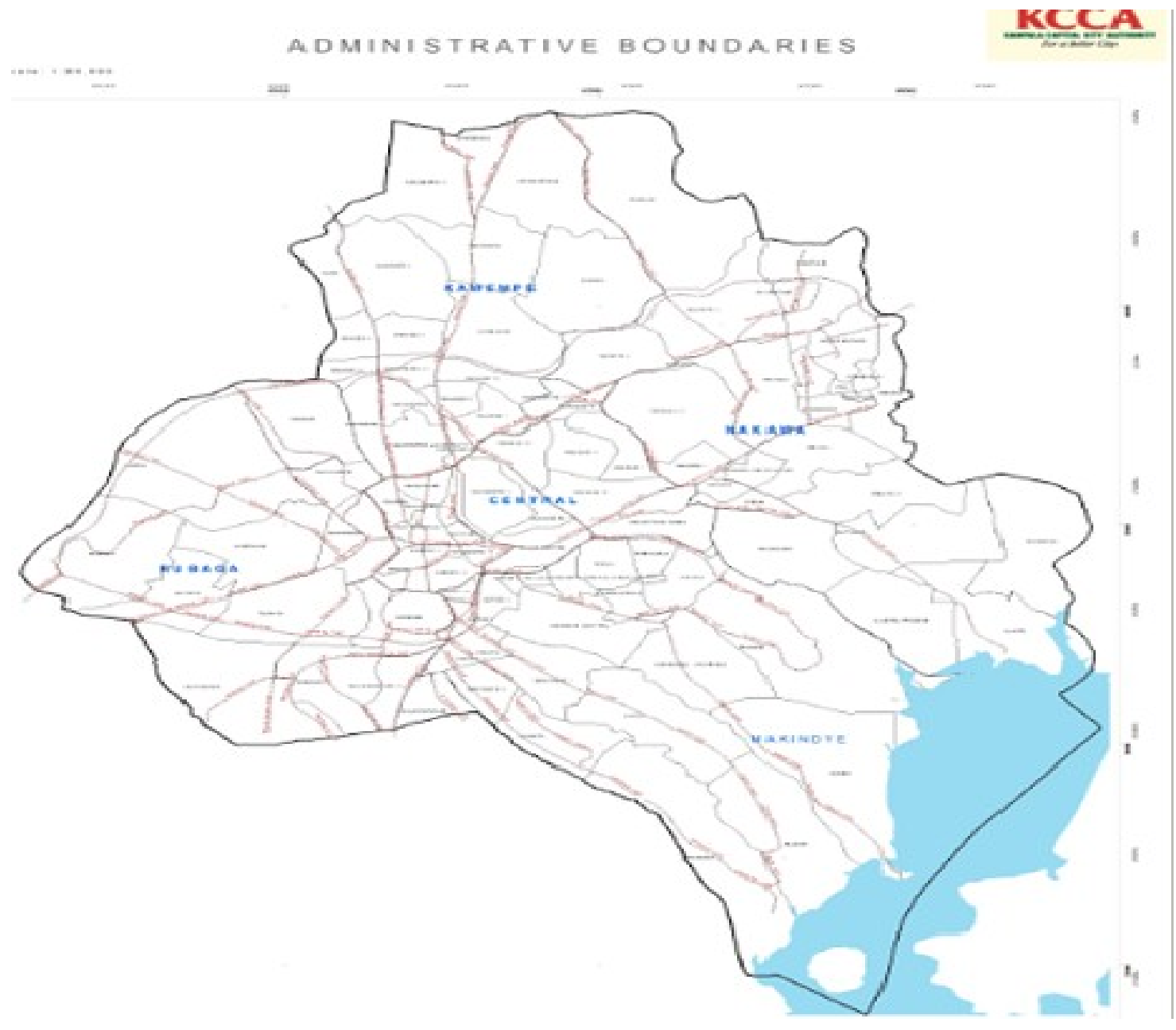

IV. Generation Trend among different divisions under KCCA

Uganda is a poor developing country, that is landlocked approximately 800 kilometers interior from the Indian Ocean and transverse by the equator, it lies on the shores of Lake Victoria Northwestern part, spreading from South (1) and North (4) latitude and 30 -35 east longitude. Uganda is boarded by Kenya to the East, Tanzania and Rwanda in the South, Sudan in the North and Zaire to the West. Uganda's land surface is about 241,139 Square Kilometers, Uganda inhabits a big portion of Lake Victoria Basin and the small islands i.e., Sese islands are also found in Uganda since they lie in Lake Victoria along the borders. According to available data from KCCA, per capita generation of garbage is one kilogram per day. It was a challenge to get hands on the secondary data in KCCA by the time this research was conducted since the new management in place has skeleton staff with most of the positions yet to be filled as the organization structure was yet to be approved by the minister for Kampala. However, archives were not kept due to total change from Kampala City Council (KCC) to KCCA and owing to management settling the pending leadership issues for the city, the situation was only conducive for primary data collection. KCCA is supervising five divisions i.e., Kampala Central, Kawempe, Lubaga, Makindye and Nakawa to ensure that solid waste is properly collected and dumped in the landfill.

Solid waste collection in Kampala is free service to the poor people living in slums of Kawempe, Kampala central, Lubaga, Makindye and Nakawa divisions. However commercial businesses pay for their garbage collection using registered garbage collectors with National Environmental Management Authority (NEMA) and KCCA.

KCCA is an implementation agency for NEMA and they ( KCCA) act for and on behalf of NEMA through the use of the garbage Ordinance of 2000 (KCC, 2000) to implicate culprits who are found illegally dumping waste. There are 60 registered garbage collectors in the city but KCCA does not levy tax for collecting garbage. The underlying reason behind free garbage collection in Kampala was reckless disposal of garbage on the main roads and water channels which later resulted into serious city floods that displaced and killed many people (Bradshaw, Sodhi, PEH, \& Brook, 2007). Since there is lack of planned settlements in Uganda, this resulted into careless settlement justified by poverty songs. As a result there was a failure to manage domestic waste hence resulting into carelessly dumping. Management of solid waste requires big investment which 
Government cannot afford. Therefore administrators in KCCA were required to be innovative to think of ways to increase efficiency in solid waste and at the same time reduce costs. This gave birth to the concept of "sharing solid waste management services" which has resulted into improved solid waste management in the city.

\section{Results}

The table below indicates estimated weight of garbage generated from the five divisions of KCCA namely; Kampala Central, Kawempe, Lubaga, Makindye and Nakawa. The results indicate that Kampala Central produces the highest tonnage of waste as compared to the rest of the four divisions. The generation is also affected by seasons i.e., Kampala central tonnage increases sharply during March, April, July and August.

Table: 1. Waste generation in KCCA Uganda in financial year 2012-2013.

\begin{tabular}{|c|c|c|c|c|c|c|c|c|c|c|c|c|}
\hline \multirow[b]{3}{*}{ DIVISION } & \multicolumn{4}{|c|}{ Estimated weight [tons] } & & & & & & & & \\
\hline & \multicolumn{3}{|c|}{ QUARTER I } & \multicolumn{3}{|c|}{ QUARTER II } & \multicolumn{3}{|c|}{ QUARTER III } & \multicolumn{3}{|c|}{ QUARTER IV } \\
\hline & July & Aug & Sept & Oct & Nov & Dec & 13-Jan & $13-\mathrm{Feb}$ & 13-Mar & 13-Apr & $\begin{array}{r}13- \\
\text { May } \\
\end{array}$ & 13-Jun \\
\hline CENTRAL & 6,751 & 5,708 & 5028.5 & 5147.8 & 5005 & 5339.1 & 5502.8 & 4568.3 & 5566.7 & 5435.4 & 5373.5 & 4745 \\
\hline KAWEMPE & 3,014 & 3,122 & 3038.9 & 2986.7 & 3013.4 & 3288.2 & 3278.1 & 2971.5 & 3586.9 & 3037.1 & 2972.6 & 2729.7 \\
\hline LUBAGA & 3,341 & 3,977 & 2822 & 3173.2 & 3275.3 & 3358.8 & 3484.2 & 3214.7 & 3735.8 & 3609.9 & 3614.5 & 3908 \\
\hline MAKINDYE & 1,853 & 2,371 & 1978.3 & 2566.4 & 2450.1 & 2266.6 & 1964.5 & 2029.8 & 3173.3 & 2969.8 & 3452 & 3059.7 \\
\hline NAKAWA & 3,615 & 3,787 & 3290.6 & 3556.1 & 3510.5 & 3758.9 & 3110.9 & 2850 & 3297.5 & 2847.3 & 2590.5 & 2598.8 \\
\hline
\end{tabular}

Generation is high during Quarter 1 and 2 for KCCA and low lowest in Quarter 3 while for private contractors, their collection increases during Quarter 3 and 4 and lowest during Quarter one as indicated in table 2 below;

Table: 2. Total tonnes and percentage weight tons per quarter for both private and KCCA for financial year 2012- 2013.

\begin{tabular}{|c|c|c|c|}
\hline Quarters & KCCA & Private & TOTAL \\
\hline Quarter 1 & $(68.30 \%){ }^{58,816}$ & ${ }_{(31.70 \%)^{27,304}}$ & 86119.8 \\
\hline Quarter 2 & $(64.09 \%))^{56,414}$ & $(35.91 \%)^{31,615}$ & 88029.1 \\
\hline Quarter 3 & $(61.59 \%) \quad 53,930$ & $(38.41 \%)^{33,627}$ & 87556.18 \\
\hline Quarter 4 & $\begin{array}{ll} & 56,668 \\
(63.48 \%) & \end{array}$ & $(36.52 \%)^{32,603}$ & 89270.3 \\
\hline
\end{tabular}

Figure: 2 Shows KCCA and Private Contactors collection in financial year 2012-2013.

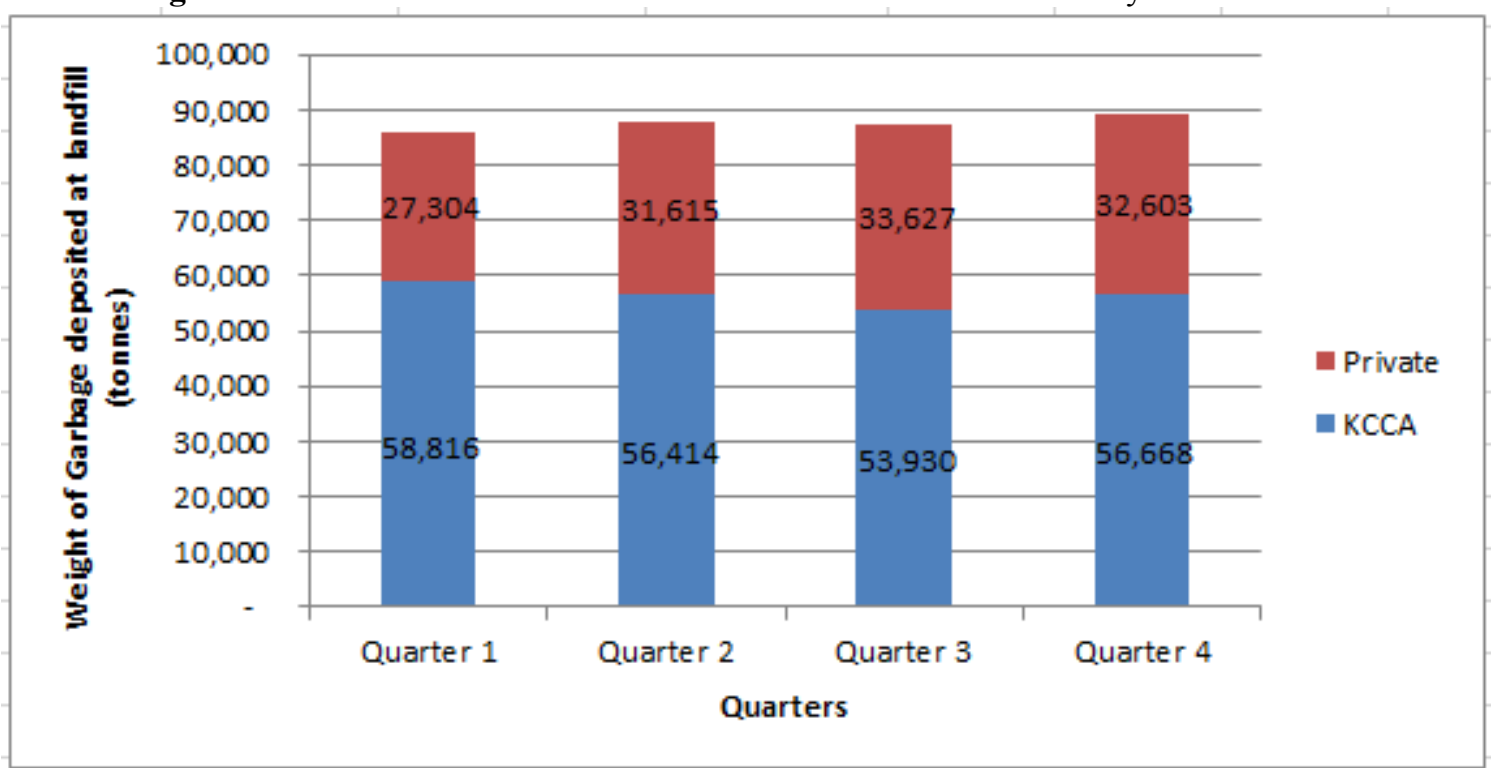

Figure 2 below shows clearly that government of government still has an upper hand in generation and management of solid waste in Kampala City throughout the year.

\section{Discussions}


Table 1 indicates that Kampala central generates more garbage compared to other divisions in KCCA, followed by Lubaga, Kawempe, Nakawa and Makindye. Therefore budget for solid waste management should be allocated depending the tonnage generated by each division. In this case, Kampala Central's garbage collection budget should be doubled to enable division's solid waste staff to plan and eliminate garbage in the city.

Policy makers and KCCA senior administration should use the tonnage information to guide the policy and decision making, for example the number of equipments used and casual staff vary greatly from one division to another depending the generated solid waste.

According to the available documents and observation, (Authority, 20012-2013) the amount of generated tonnage has increased and this can be attributed to the current "shared solid waste management model" of delivery. In this model, all the five division were amalgamated into one central body called KCCA. It was assumed that scale leads to efficiency (Dollery \& Akimov, 2008; Dollery \& Crase, 2004). The available resources under this model have been shared like the garbage trucks, causal workers and heavy equipments i.e., wheel loaders to facilitate increased collection of garbage and disposal thus increasing efficiency in collection from 55\%- 65\% (Madinah, 2014, 2015).

Though the model has been proven significant, it can lead to over exploitation which has negative consequences to KCCA in future. One would not be wrong to conclude that scale led to increased efficiency in solid waste management at least in Uganda (Sørensen, 2006) since observation results indicate a modest improvement of a certain level of sanitation on the streets in the City center.

Since this study was performed in the city center, before being replicated, further research should done with the case study of municipalities to ascertain whether the model gives positive results before the policy is guided for shared solid waste in Uganda.

Sharing solid waste has resulted into instant improvement of sanitation conditions in the city. At least on all the main roads and the water channels, there is commitment to ensure Kampala imitates a beautiful and clean city like those in developing countries such as Malaysia. The modest improvement in solid waste efficiency can be viewed instantly within the city as shown in the pictures below in figure 3 .

Figure 3 indicates the trend of solid waste on the main roads of Kampala

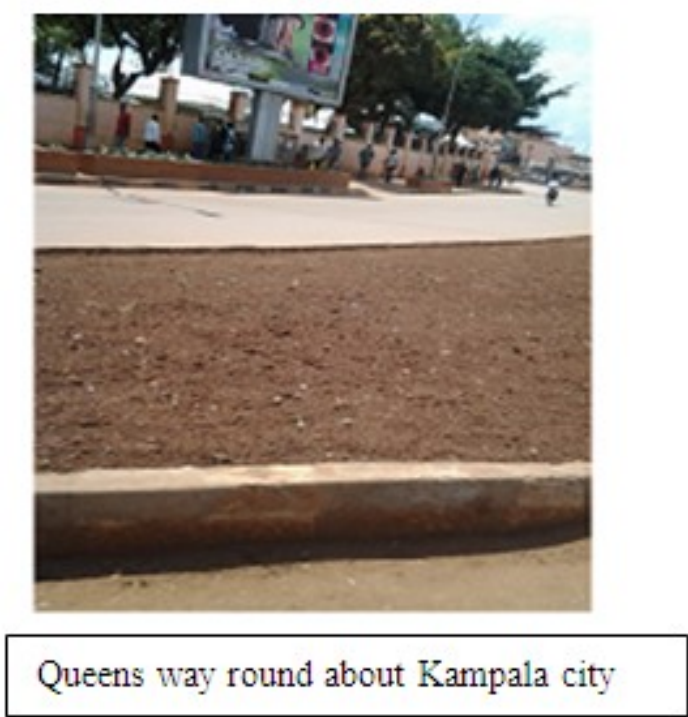

However since the solid waste backlog in the suburb areas of Kampala is still a challenge as sharing has not reached its optimal level of performance in ensuring improved sanitations in the city ( figures 4 and 5 below); 
Figure 4 and 5: indicates the trend of solid waste in Kampala suburbs

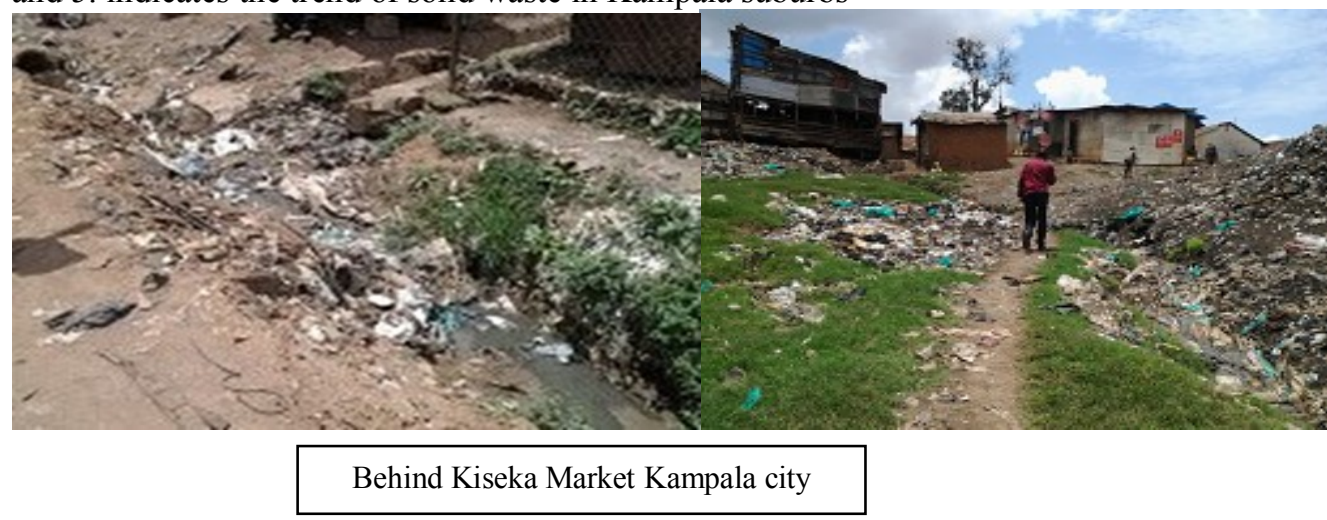

In conclusion, KCCA has not achieved the optimal level of performance as far as solid waste management is concerned. Though modest improvement has been registered in the middle of the city center, a lot has to be done to keep the entire suburbs of the city equally clean to prevent serious diseases that accrue as a result of uncollected waste.

It can be argued that, the centralized structure of KCCA is appropriate for the performance of the task since it separates politics and administration. There is fair degree of autonomy in the delivery of services and the changes are implemented without fear or favor to benefit all Ugandans.

We also propose that government allocates funds according to percentage generation of waste and on this basis, KCCA needs to place emphasis on reduction of waste generation by ensuring sustainable reuse and recycling as well as addressing key success factors including expertise, awareness of the public, strengthening partnerships to pool resources and promoting advanced technology. In spite of its short comings of the model being used to eliminate waste, by and large sharing solid waste has proved to increase solid waste management efficiency by $10 \%$ in the last 2 years hence the model should be encouraged.

\section{References}

[1]. Achankeng, E. (2003). Globalization, urbanization and municipal solid waste management in Africa. Paper presented at the Proceedings of the African Studies Association of Australasia and the Pacific 26th Annual Conference.

[2]. Authority, K. C. C. (20012-2013). Ministrial Policy Statement on Kampala Capital City Authority Government of Uganda, 1, 94

[3]. Bradshaw, C. J., Sodhi, N. S., PEH, K. S. H., \& Brook, B. W. (2007). Global evidence that deforestation amplifies flood risk and severity in the developing world. Global Change Biology, 13(11), 2379-2395.

[4]. Dollery, B., \& Akimov, A. (2008). A Critical Comment on the Analysis of Shared Services in the Queensland Local Government Association's Size, Shape and Sustainability Program. Accounting, Accountability \& Performance, 14(2), 29.

[5]. Dollery, B., \& Crase, L. (2004). Is bigger local government better? An evaluation of the case for Australian municipal amalgamation programs. Urban Policy and Research, 22(3), 265-275. doi: 10.1080/0811114042000269290

[6]. ERL, E. R. L. (2009). Solid Waste Disposal -Kampala Final Report. Government of Uganda, -(-), 68.

[7]. Golooba-Mutebi, F. (2003). Devolution and outsourcing of municipal services in Kampala city, Uganda: an early assessment. Public Administration \& Development, 23(5), 405-418.

[8]. KCC. (2000). Solid Waste Management SWM Ordinance 2000. Uganda, 19.

[9]. KCCA. (2013). Statement on the issues of Kampala Capital City Authority. Government of Uganda, 17.

[10]. Lambright, G. (2014). Opposition politics and urban service delivery in Kampala, Uganda. Development Policy Review, 32(s1), s39-s60.

[11]. Liyala, C. M. (2011). Modernising solid waste management at municipal level: institutional arrangements in urban centres of East Africa (Vol. 3): Wageningen Academic Pub.

[12]. Madinah, N., Boerhannoeddin, A., \& Ariffin, R. N. B. R. (2014). Performance Assessment of Public Service Organisations in Shared Solid Waste Services: A case for Kampala Capital City Authority in Uganda. . World Journal of Social Science, 1(2), 86.

[13]. Madinah, N., Boerhannoeddin, A., \& Ariffin, R. N. B. R. (2015). Performance Evaluation of Public Service Institutions (CQS) Framework. . World Journal of Social Science, 2(1), 1-12.

[14]. Manaf, L. A., Samah, M. A. A., \& Zukki, N. I. M. (2009). Municipal solid waste management in Malaysia: Practices and challenges. Waste Management, 29(11), 2902-2906.

[15]. Matagi, S. V. (2002). Some issues of environmental concern in Kampala, the capital city of Uganda. Environmental Monitoring and Assessment, 77(2), 121-138.

[16]. Okot-Okumu, J., \& Nyenje, R. (2011). Municipal solid waste management under decentralisation in Uganda. Habitat International, 35(4), 537-543. doi: 10.1016/j.habitatint.2011.03.003

[17]. Okot-Okumu, J., \& Oosterveer, P. (2010). Providing sanitation for the urban poor in Uganda Social perspectives on the sanitation challenge (pp. 49-66): Springer.

[18]. Samah, M. A. A., Manaf, L. A., Ahsan, A., Sulaiman, W. N. A., Agamuthu, P., \& D'Silva, J. L. (2013). Household solid waste composition in Balakong City, Malaysia: trend and management. Polish Journal of Environmental Studies, 22(6), 1807-1816.

[19]. Sørensen, R. J. (2006). Local government consolidations: The impact of political transaction costs. Public Choice, 127(1-2), 75-95. doi: $10.1007 / \mathrm{s} 11127-006-7106-8$

[20]. Tukahirwa, J. T., Mol, A. P., \& Oosterveer, P. (2010). Civil society participation in urban sanitation and solid waste management in Uganda. Local Environment, 15(1), 1-14.

[21]. UBOS, U. B. o. S. (2005). Uganda Population and Housing Census Kamapal District Report Government of Uganda, -(-), 203. 